\title{
Pengaruh Konsentrasi Asam Klorida pada Arang Aktif Kulit Kelapa Muda untuk Menurunkan BOD dan DO Limbah Cair Tahu
}

\section{Effect of Activator Concentration of Hydrochloric Acid in Activited Carbon from Young Coconut Fiber to Decrease BOD and DO at Waste Liquid Tofu}

\author{
Sumardiyono $^{1^{*}}$ dan Soebiyanto ${ }^{2}$ \\ ${ }^{1}$ Program Studi S1 Teknik Kimia, Fakultas Teknik \\ ${ }^{2}$ Program Studi D-III Analis Kesehatan, Fakultas Ilmu Kesehatan \\ Universitas Setia Budi Surakarta \\ Jl. Letjen Sutoyo Mojosongo, Surakarta, Jawa Tengah 57121 \\ *Corresponding Author : dionsumarjo@gmail.com \\ Received: February 30, 2019; Revise: April 15, 2019; Accepted: May 7, 2019 \\ DOI : https://doi.org/10.31001/biomedika.v12i1.466
}

\begin{abstract}
ABSTRAK
Telah dilakukan penelitian pembuatan arang aktif dari kulit kelapa muda dengan aktifvator asam klorida yang akan digunakan sebagai adsorben pada limbah cair tahu. Pembuatan adsorben dari kulit kelapa muda ini dilanjutkan dengan uji kemampuannya untuk mengadsorpsi BOD dan DO pada limbah cair tahu. Pembuatan karbon aktif kulit kelapa muda dilakukan melalui pemilihan pencucian, pengeringan, pengarangan, aktivasi menggunakan asam klorida dengan variabel waktu perendaman. Untuk pengujian BOD dan DO dilakukan dengan metode titrasi. Konsentratrasi asam klorida yang dipergunakan $0,5 \mathrm{~N} ; 1 \mathrm{~N} ; 1,5 \mathrm{~N} ; 2 \mathrm{~N}$; dan $2,5 \mathrm{~N}$ dengan waktu perendaman masing-masing konsentrasi 0,5 jam, 1 jam, 1,5 jam, 2 jam dan 2,5 jam. Setelah jadi arang aktif kemudian dipergunakan untuk menyerap limbah cair tahu. Hasil percobaan didapatkan hasil yang terbaik adalah pada konsentrasi $2,5 \mathrm{~N}$. Untuk waktu perendaman 0,5 jam besarnya DO $2013 \mathrm{mg} / \mathrm{l}$, efisiensinya $86,91 \%$ dan besarnya BOD $284 \mathrm{mg} / 1$ efisiensi $87,64 \%$. Untuk waktu perendaman 1 jam besarnya DO $2015 \mathrm{mg} / \mathrm{l}$ efisiensinya $87,64 \%$ dan besarnya BOD $267 \mathrm{mg} / \mathrm{l}$ efisiensi $88,38 \%$. Untuk waktu perendaman 1,5 jam besarnya DO $2002 \mathrm{mg} / 1$ efisiensinya $86,52 \%$ dan besarnya BOD $305 \mathrm{mg} / \mathrm{l}$ efisiensnyai $86,72 \%$. Untuk waktu perendaman 2 jam besarnya DO $1833 \mathrm{mg} / 1$ efisiensinya $86,25 \%$ dan besarnya BOD $314 \mathrm{mg} / \mathrm{l}$ efisiensinya $86,33 \%$. Untuk waktu perendaman 2,5 jam besarnya DO $1971 \mathrm{mg} / \mathrm{l}$ efisiensinya $86,17 \%$ dan besarnyaBOD $313 \mathrm{mg} / 1$ efisiensinya $86,37 \%$. jadi dapat disimpulkan untuk hasil terbaik BOD yaitu pada konsentrasi asam klorida 2,5 $\mathrm{N}$ dengan waktu perendaman 1 jam, besarnya BOD $267 \mathrm{mg} / 1$ dengan efisiensi sebesar 88,38\%, dan besarnya DO konsentrasi asam klorida 2,5 $\mathrm{N}$ waktu perendaman 1 jam besarnya DO $2015 \mathrm{mg} / \mathrm{l}$ dengan efisiensi $87,64 \%$.
\end{abstract}

Kata Kunci : kulit kelapa muda; arang aktif; BOD; DO

\section{ABSTRACT}

Research had been conducted on making activated charcoal from young coconut skin with hydrochloric acid as an activator which would be used as an adsorbent in tofu liquid waste. The making of the adsorbent from young coconut skin was continued by testing its ability to adsorb BOD 
and DO in tofu liquid waste. Making activated carbon from young coconut skin was done through the selection of washing, drying, drying, activation using hydrochloric acid with immersion time variables. Titration method was used to test the BOD and DO.Concentration of hydrochloric acid used $0.5 \mathrm{~N} ; 1 \mathrm{~N} ; 1.5 \mathrm{~N} ; 2 \mathrm{~N}$; and $2.5 \mathrm{~N}$ with immersion times of each concentration of 0.5 hours, 1 hour, 1.5 hours, 2 hours and 2.5 hours. Activated charcoal then was used to absorb tofu liquid waste. From the experiment the best results were obtained at a concentration of $2.5 \mathrm{~N}$. For 0.5 hour immersion time, DO was $2013 \mathrm{mg} / \mathrm{l}$ with efficiency $86.91 \%$ and the BOD was $284 \mathrm{mg} / \mathrm{l}$ with efficiency $87.64 \%$. For the 1 hour immersion time, DO was $2015 \mathrm{mg} / \mathrm{l}$ with efficiency $87.64 \%$ and the BOD was $267 \mathrm{mg} / \mathrm{l}$ with efficiency 88.38\%. For 1.5 hours of immersion time DO was $2002 \mathrm{mg} / \mathrm{l}$ with efficiency $86.52 \%$ and the amount of BOD was $305 \mathrm{mg} / \mathrm{l}$ with efficiency $86.72 \%$. For 2 hours immersion time DO was $1833 \mathrm{mg} / \mathrm{l}$ with efficiency $86.25 \%$ and the amount of BOD was $314 \mathrm{mg} / \mathrm{l}$ with efficiency $86.33 \%$. For the immersion time of 2.5 hours the DO amount was $1971 \mathrm{mg} / \mathrm{l}$ with efficiency $86.17 \%$ and the amount of BOD was $313 \mathrm{mg} / \mathrm{l}$ with efficiency $86.37 \%$. so it can be concluded that the best BOD results are at $2.5 \mathrm{~N}$ hydrochloric acid concentration with 1 hour immersion time, BOD size $267 \mathrm{mg} / \mathrm{l}$ with an efficiency of $88.38 \%$, and DO size $2.5 \mathrm{~N}$ hydrochloric acid concentration 1 hour immersion time DO amount was $2015 \mathrm{mg} / \mathrm{l}$ with efficiency of $87.64 \%$

Keywords: young coconut skin; activated charcoal; $B O D$; $D O$

\section{PENDAHULUAN}

Lokasi industri tahu di Indonesia sebagian besar berdampingan dengan pemukiman penduduk, sehingga muncul banyak permasalahan dengan warga sekitar (Ratnani, 2012), sebab dalam proses pengolahannya, industri tahu menghasilkan limbah yaitu limbah padat dan limbah cair. Limbah cair tahu yang langsung dibuang dapat menurunkan kualitas lingkungan (Kaswinarni, 2008).

Karakteristik limbah tahu khususnya limbah cair tahu mengandung bahan organik yang tinggi, suhunya mencapai $40^{\circ} \mathrm{C}-46^{\circ} \mathrm{C}$, kadar BOD di limbah cair tahu $6000-8000 \mathrm{mg} / 1$,. Limbah cair tahu juga mengandung $\mathrm{pH}$ dan TSS yang cukup tinggi. Gas-gas yang terkandung dalam limbah tahu diantaranya gas nitrogen $\left(\mathrm{N}_{2}\right)$, oksigen $\left(\mathrm{O}_{2}\right)$, hidrogen sulfida $\left(\mathrm{H}_{2} \mathrm{~S}\right), \quad$ amonia $\left(\mathrm{NH}_{3}\right)$, karbondioksida $\left(\mathrm{CO}_{2}\right)$, dan metana $\left(\mathrm{CH}_{4}\right)$. Senyawa gas tersebut sangat beracun bagi sebagian besar makhluk hidup. Limbah cair tahu yang berada di atas ambang batas tersebut menyebabkan ketidaknyamanan yang berupa bau menyengat serta dapat mengganggu kesehatan khususnya yang berkaitan dengan air yang kotor serta kualitas lingkungan yang tidak baik (Herlambang, 2002).

Salah satu metode pengolahan limbah cair dapat melalui proses adsorpsi menggunakan karbon aktif atau arang aktif dari bahan bakar limbah yang mengandung karbon (Sembiring dan Sinaga, 2003). Penggunaan metode ini dikarenakan metode ini relatif sederhana dan efektif. Pada pengolahan air, karbon aktif berguna untuk menyisihkan rasa, bau, dan warna (Sembiring dan Sinaga, 2003).

Penelitian mengenai pengolahan limbah cair tahu dan pemanfaatan kulit kelapa muda sebagai adsorben telah banyak dilakukan oleh peneliti-peneliti sebelumnya. Beberapa diantaranya, penelitian tentang penurunan BOD dan DO pada limbah cair industri tahu menggunakan zeolit teraktivasi pernah dilakukan oleh (Ariani, 2015), menghasilkan penurunan BOD 79,75\%. 
Penelitian tentang penurunan kadar amonia, nitrit, dan nitrat limbah cair industri tahu menggunakan arang aktif dari ampas kopi juga pernah dilakukan dan dihasilkan penurunan sebesar 64,69\%; $52,35 \%$; dan $86,40 \%$ pada waktu kontak dan $\mathrm{pH}$ optimum (Irmanto dan Suyata, 2009). Dalam penelitian tentang pemanfaatan limbah kulit kelapa muda sebagai karbon aktif menghasilkan penyerapan terbaik terhadap iodine untuk aktivator $\mathrm{HCl}$ sebesar 45,685\%. Penelitian tentang penurunan kadar BOD,dan DO limbah cair industri tahu menggunakan arang aktif dari kulit pisang juga pernah dilakukan dan dihasilkan penurunan sebesar 94,78\%; 94,77\%; pada waktu kontak 150 menit.( Dewati R .2008)

Berdasar penelitian-penelitian yang telah dilakukan oleh beberapa peneliti sebelumya, penelitian untuk mengetahui besar penurunan BOD dan DO yang terjadi apabila diolah menggunakan arang aktif dari kulit kelapa muda dengan variasi konsentrasi aktivator $\mathrm{HCl}$, belum pernah dilakukan. Hal inilah yang membedakan penelitian yang akan dilakukan dengan penelitian-penelitian sebelumnya.(Lantang 2017)

Adapun tujuan yang ingin dicapai dari penelitian ini adalah mengetahui konsentrasi aktivator optimum asam klorida pada arang aktif kulit kelapa muda untuk mendapatkan kapasitas maksimum dalam proses adsorpsi limbah cair tahu.

\section{METODE PENELITIAN}

\section{Alat dan Bahan}

Alat yang digunakan adalah $\mathrm{pH}$ meter, BOD meter, furnace, Botol BOD dan inkubator. Bahan utama yang digunakan dalam penelitian ini adalah sampel limbah cair tahu yang diambil dari pabrik di salah satu Dusun di Kelurahan Mojosongo, Kecamatan Jebres, Surakarta, dan kulit kelapa muda yang diperoleh dari pedagang kelapa muda disekitar solo

Bahan pembantu yang digunakan untuk arang aktif adalah $\mathrm{HCl}$ teknis, untuk BOD yaitu Larutan penyangga (buffer) fosfat, Larutan Magnesium Klorida, Larutan Kalsium Klorida, Larutan $\mathrm{FeCl}_{3}$, Larutan $\mathrm{MnSO}_{4}$ dan alkali azida, $\mathrm{HCl}$ pekat, Larutan standar Thioklorida, serta Indikator Amilum 0,5 \%, Larutan Kalium Bikromat standart, Asam Klorida pekat, Larutan Ferro Amonium Klorida, Indikator Ferroin dan batu didih.

\section{Prosedur Penelitian}

Pembuatan adsorben kulit kelapa muda dilakukan dengan cara, kulit kelapa muda dipotong dengan ukuran $5 \mathrm{~cm}^{2}$, dicuci kemudian dikeringkan dengan sinar matahari selama \pm 7 hari. Selanjutnya kulit kelapa muda tersebut dimasukkan ke dalam furnace dengan suhu $200^{\circ} \mathrm{C}$ selama 1 jam kemudian dilanjutkan pada suhu $300^{\circ} \mathrm{C}$ selama jam. Setelah menjadi arang, dibiarkan dingin dalam desikator. Arang kulit kelapa muda dikeringkan kembali dalam oven pada suhu $105^{\circ} \mathrm{C}$ untuk mengurangi kadar air yang masih terkandung didalamnya. Kemudian arang kulit kelapa muda dihaluskan dan diayak menggunakan ayakan.

Selanjutnya arang diaktivasi menggunakan larutan HCL dengan variasi konsentrasi larutan HCL $0,5 \mathrm{~N} ; 1,0 \mathrm{~N} ; 1,5$ $\mathrm{N} ; 2 \mathrm{~N}$ dan 2,5 N. Kemudian distirer selama 2 menit kemudian direndam masing-masing konsentrasi dengan 
variabel waktu 0,5 jam, 1 jam, 1,5 jam, 2 jam dan 2,5 jam . Dicuci dengan akuades hingga netral, setelah disaring lalu dipanaskan kembali dalam oven pada suhu $105^{\circ} \mathrm{C}$. Setelah itu, didinginkan dalam desikator, ditimbang dan dikeringkan berulang kali hingga diperoleh berat konstan.( Arung . S 2014 )

Sebanyak 10 gram arang aktif dengan berbagai konsentrasi yang sudah jadi dicampur dengan $200 \mathrm{ml}$ limbah cair tahu Campuran tersebut distirer kecepatan selama 2 menit, disaring dan limbah cair tahu yang terpisah dianalisis kadar DO dan BOD ( Ariani, A. T. 2015).

\section{Analisis Data}

Nilai BOD contoh uji dihitung sebagai berikut :

$\mathrm{BOD}=\frac{\left(\mathrm{A}_{1}-\mathrm{A}_{2}\right)-\left(\frac{\left(\mathrm{B}_{1}-\mathrm{B}_{2}\right.}{\mathrm{V}_{\mathrm{B}}}\right) \mathrm{V}_{\mathrm{C}}}{\mathrm{P}}$

dengan pengertian :

BOD adalah nilai BOD contoh uji (mg/l);

$\mathrm{A}_{1}$ adalah kadar oksigen terlarut contoh uji sebelum inkubasi (0 hari) (mg/l);

$\mathrm{A}_{2}$ adalah kadar oksigen terlarut contoh uji sebelum inkubasi 5 hari (mg/l);

$\mathrm{B}_{1}$ adalah kadar oksigen terlarut blanko sebelum inkubasi (0 hari) (mg/l);

$\mathrm{B}_{2}$ adalah kadar oksigen terlarut blanko sebelum inkubasi 5 hari (mg/l);

$\mathrm{V}_{\mathrm{B}}$ adalah volume suspensi mikroba (mL) dalam botol DO blanko;

$\mathrm{V}_{\mathrm{C}}$ adalah volume suspensi mikroba $(\mathrm{mL})$ dalam botol contoh uji (ml);

$\mathrm{P}$ adalah perbandingan volume contoh uji $\left(\mathrm{V}_{1}\right)$ per volume total $\left(\mathrm{V}_{2}\right)$.

$\mathrm{BOD}=\frac{(\text { BOD awal-BOD akhir }) \times \mathbf{1 0 0} \%}{\text { BOD awal }}$

\section{HASIL DAN PEMBAHASAN}

Hasil Analisa BOD,DO Limbah Cair Tahu dengan Perlakuan Arang Aktif Kulit kelapa muda dapat dilihat pada Gambar 1, 2 dan 3. Hasil yang terlihat bahwa untuk $0,5 \mathrm{~N}, 1 \mathrm{~N}, 1,5 \mathrm{~N}, 2 \mathrm{~N}$ dan 2,5 $\mathrm{N}$ dengan variasi waktu perendaman 0,5 jam, 1 jam, 1,5 jam, 2 jam, dan 2,5 jam. Besarnya hasil perhitungan efisiensi berdasarkan konsentrasi 2,5 $\mathrm{N}$ dan untuk waktu perendaman 1 jam didapatkan hasil efisiensi sebagai berikut tersebut, $88,38 \%$ untuk BOD, 87,64\% DO.

Hubungan waktu perendaman dengan BOD

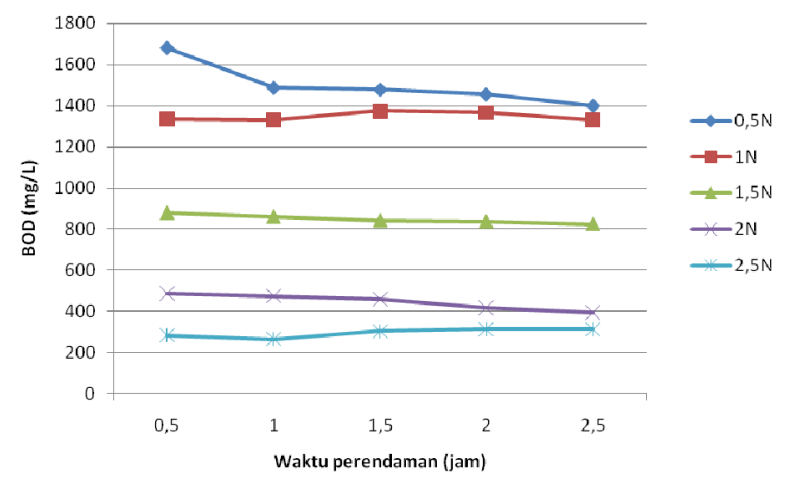

Gambar 1. Grafik hubungan waktu perendaman dengan BOD

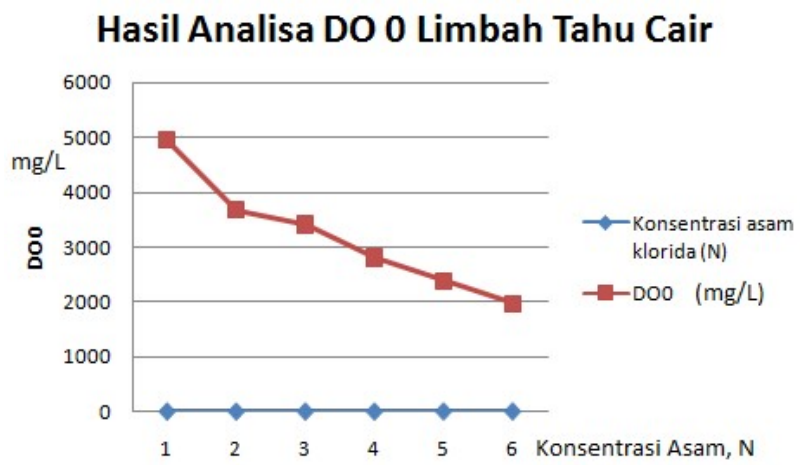

Gambar 2. Grafik hasil analisa DO awal limbah tahu cair 


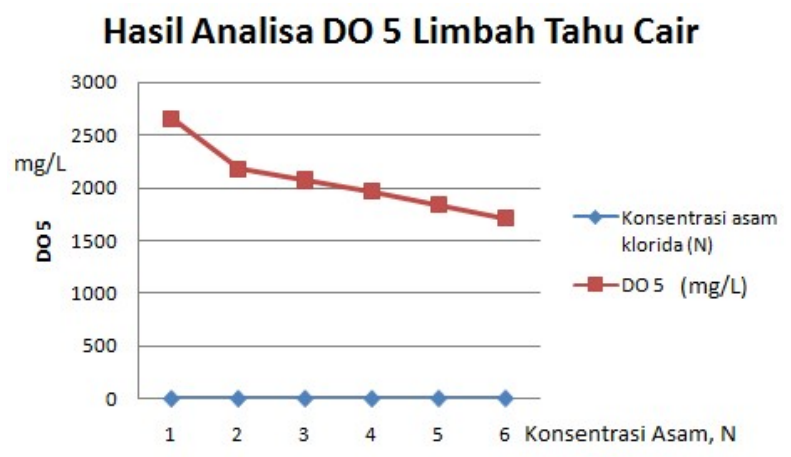

Gambar 3. Grafik hasil analisa DO 5 limbah tahu cair.

Konsentrasi asam klorida yang semakin meningkat maka untuk mengaktivasi adsorben maka akan semakin besar proses adsorpsi yang terjadi. (Arung. S 2014) Daya serap arang aktif semakin kuat bersamaan dengan meningkatnya konsentrasi dari aktivator yang ditambahkan, dengan sifat aktivator yang mampu menghilangkan unsur logam dan mampu menambah unsur karbon maka daya serap pada karbon semakin besar. Penelitian yang lain ini sebagian menggunakan jenis asam kuat untuk pertentangannya belum ada peneliti yang mengklaim bahwa aktivator asam kuat ini yang paling bagus (Erawati, 2018). Penelitian kedepannya selain konsentrasi aktivator adalah suhu aktivasi atau ukuran partikel arangnya.

\section{KESIMPULAN}

Kosentrasi asam klorida yang berkadar 2,5 $\mathrm{N}$ dan waktu perendaman 1 jam adalah yang terbaik untuk activator arang aktif dengan efisiensi sebesar 88,38 $\%$.

\section{DAFTAR PUSTAKA}

Ariani, A. T. 2015. Penurunan BOD (Biochemica Oxygen Deman) DAN COD (Chemical Oxygen Demen) Pada Limbah Cair Industri Tahu Menggunakan Zeolit Teraktivasi. UIN
Sunan Kalijaga Yogyakarta Retrieved from http://digilib.uin-suka.ac.id/15714/

Arung, S. 2014. Pengaruh Konsentrasi Aktivator Asam Klorida Pada Pembuatan Karbon Aktif. Al-Kimia. 52-63.

Darmayanti, D., Rahman, N., \& Supriadi, S. 2012. Adsorbsi Timbal dan Zink Dari Larutannya Menggunakan Arang Kulit Kelapa Muda. Jurnal Akademika Kimia 1(4) 159-163.

Dewati, R. 2008. Limbah Kulit Kelapa Muda Sebagai Bahan Pembuat Etanol. UPN "Veteran" Jatim. Jurnal JTM 02(01) 57-64

Erawati. E. 2018. Pengaruh Aktivator dan Ukuran Partikel Pada Pembuatan Karbon Aktif Terhadap Pembuatan Adsorbent dari Serbuk Gergaji Kayu Sengon (Paraserianthes Falcataria). Jurnal Integrasi Proses 7(2) 58 66

Herlambang, A. 2002. Teknologi Pengolahan Limbah Cair Industri . Pusat Pengkajian dan Penerapan Teknologi Lingkungan (BPPT) dan Bapedal Samarinda.

Irmanto, S dan Suyata. 2009. Penurunan Kadar Amonia, Nitrit, dan Nitrat Limbah Cair Industri Tahu Menggunakan Arang Aktif Dari Ampas Kopi. Molekul 4(2) 105-114.

Kaswinarni, F. 2008 Kajian Teknik Pengolahan Limbah Padat dan Cair Industri Tahu. Majalah Lontar 22(2) $1-20$.

Lantang. 2017. Pengaruh Asam Kuat Sebagai Aktivator Pada Pembuatan Karbon Aktif Dari Kulit Pisang. Jurnal Ilmiah Farmasi 3 (2) 107-114

Nasir, N. S. W., Nurhaeni, N., \& Musafira, M. 2014. Pemanfaatan Arang Aktif Kulit Kelapa Muda Sebagai Absorben Untuk Menurunkan Angka Peroksida dan Asam Lemak Bebas Minyak Goreng Bekas. Online Jurnal of Natural Science 3(1): 18-30

Pujiono, F. 2017. Pembuatan Karbon Aktif Dari Limbah Pertanian Dengan Aktivator $\mathrm{HCl}$, $\mathrm{H}_{2} \mathrm{SO}_{4}$ dan $\mathrm{H}_{3} \mathrm{PO}_{4}$. Jurnal Wijaya 4(1).

Ratnani, R.D. 2012. Kecepatan Penyerapan Zat Organik Pada Limbah Cair Industri Tahu. Jurnal Ilmiah Momentum 7 (2) 18-24.

Rochma, N. 2017. Penurunan BOD Pada Limbah Industri dengan Karbon Aktif $\mathrm{HCl}$ Sebagai Aktivator. Jurnal Teknik ITS 6 (2) F324-F329.

Sandi, A.P. 2014. Pengaruh Aktivator Asam Kuat Dan Ukuran Pori Arang Aktif Pada Tempurung Kemiri. Jurnal Fisika Unand 3(2).

Sembiring, M. T., \& Sinaga, T. S. 2003. Arang Aktif (Pengenalan dan Proses pembuatannya). http://repository.usu.ac.id/handle/123456789/ 14 